\title{
Herbivore benefits from vectoring plant virus through reduction of period of vulnerability to predation
}

\author{
Belén Belliure · Arne Janssen · Maurice W. Sabelis
}

Received: 18 June 2007/ Accepted: 7 March 2008/Published online: 8 April 2008

(C) The Author(s) 2008

\begin{abstract}
Herbivores can profit from vectoring plant pathogens because the induced defence of plants against pathogens sometimes interferes with the induced defence of plants against herbivores. Plants can also defend themselves indirectly by the action of the natural enemies of the herbivores. It is unknown whether the defence against pathogens induced in the plant also interferes with the indirect defence against herbivores mediated via the third trophic level. We previously showed that infection of plants with Tomato spotted wilt virus (TSWV) increased the developmental rate of and juvenile survival of its vector, the thrips Frankliniella occidentalis. Here, we present the results of a study on the effects of TSWV infections of plants on the effectiveness of three species of natural enemies of $F$. occidentalis: the predatory mites Neoseiulus cucumeris and Iphiseius degenerans, and the predatory bug Orius laevigatus. The growth rate of thrips larvae was positively affected by the presence of virus in the host plant. Because large larvae are invulnerable to predation by the two species of predatory mites, this resulted in a shorter period of vulnerability to predation for thrips that developed on plants with virus than thrips
\end{abstract}

Communicated by Julia Koricheva.

B. Belliure · A. Janssen - M. W. Sabelis

Institute for Biodiversity and Ecosystem Dynamics, Section Population Biology, University of Amsterdam,

PO Box 94084, 1090 GB Amsterdam, The Netherlands

Present Address:

B. Belliure $(\square)$

Valencian Institute for Agricultural Research, Associated Entomology Unit IVIA/CIB-CSIC/UJI, Center for Plant Protection and Biotechnology, Apartado Oficial, 46113 Moncada, Valencia, Spain e-mail: belliure@ivia.es developing on uninfected plants (4.4 vs. 7.9 days, respectively). Because large thrips larvae are not invulnerable to predation by the predatory bug Orius laevigatus, infection of the plant did not affect the predation risk of thrips larvae from this predator. This is the first demonstration of a negative effect of a plant pathogen on the predation risk of its vector.

Keywords Tritrophic interactions - Preference . Prey size $\cdot$ Frankliniella occidentalis .

Tomato spotted wilt virus

\section{Introduction}

Herbivorous arthropods induce direct defences in plants, involving changes in plant quality that negatively affect growth and survival of the herbivores (Karban and Baldwin 1987; Agrawal 1998; Agrawal and Klein 2000; Belliure et al. 2005). Defences induced in plants by herbivory may also be indirect, i.e. mediated by promoting the effectiveness of the third trophic level (Price et al. 1980). For example, indirect defence may involve the emission of plant volatiles that are attractive to natural enemies of herbivores (Sabelis and Van der Baan 1983; Dicke and Sabelis 1988; Turlings et al. 1990; Dicke et al. 1990, 1998; Takabayashi and Dicke 1996; Janssen et al. 1998; Sabelis et al. 1999). Through this attraction, plants indirectly reduce the population of herbivores on them (Thaler 1999; Kessler and Baldwin 2001).

Plant pathogens also induce defences in plants, leading to the production of defence-related RNAs and proteins (Pieterse and van Loon 1999; Spoel et al. 2003). The defence induced by pathogens in plants can interact with the induced anti-herbivore defence, through cross-talk 
between the metabolic pathways activated after herbivore and pathogen attack. This cross-talk may be positive (Bostock 1999; Stout et al. 1999, 2006) or negative (Bostock 1999; Felton et al. 1999; Thaler et al. 1999, 2002a, b; Felton and Korth 2000; Pieterse and Van Loon 2004; Stout et al. 2006), depending on the herbivores and pathogens. The negative cross-talk between anti-pathogen and antiherbivore defences favours the performance of herbivore vectors on plants infected with vector-borne pathogens (Carter 1939; Bautista et al. 1995; Maris et al. 2004; Belliure et al. 2005; Stumpf and Kennedy 2007).

Most research on the negative interaction between antiherbivore and anti-pathogen defences has concentrated on direct plant defences (Thaler et al. 1999; Felton et al. 1999; Felton and Korth 2000; Thaler et al. 2002b; Pieterse and Van Loon 2004; Belliure et al. 2005), and few studies have focused on indirect plant defence, involving the action of the third trophic level (Rostas et al 2006). Nevertheless, survival of vectors and success of pathogen dispersal is negatively affected by natural enemies of vectors. Therefore, we expect pathogens to reduce the impact of natural enemies of their vectors in order to enhance their own spread. In this article, we investigate the interaction of a virus with the natural enemies of its insect vector.

The Tomato spotted wilt virus (TSWV) is a vectorborne plant virus that is transmitted horizontally by various thrips species (Thysanoptera: Thripidae), such as the Western flower thrips Frankliniella occidentalis (Pergande) (Sakimura 1962). Thrips acquire the virus as they hatch from eggs and feed on infected plants. However, not all thrips develop into virus-transmitting adults (Sakimura 1962; Nagata and Peters 2001). Western flower thrips induce anti-herbivore defences in plants (Belliure et al. 2005; Delphia et al. 2007), and have been reported to aggregate preferentially on TSWV-infected plants (Carter 1939; Bautista et al. 1995; Maris et al. 2004). This aggregation can be explained by the benefit that thrips larvae obtain when developing on TSWV-infected plants; their juvenile survival and developmental rate are higher on plants with the virus than on plants that are also attacked by thrips, yet free of the virus (Belliure et al. 2005). This suggests that the virus reduces the induced direct plant defence against thrips, thereby promoting survival and development of its vector (Belliure et al. 2005).

Important natural enemies of the thrips are predatory mites, such as the phytoseiid species Neoseiulus cucumeris (Oudemans) and Iphiseius degenerans (Berl.), and anthocorid bugs such as various Orius spp. Anthocorid bugs prey upon all juvenile stages and the adults of the thrips (van den Meiracker and Sabelis 1999), whereas phytoseiid mites feed mainly on first instar thrips larvae (Bakker and Sabelis 1986, 1989). Thrips larvae defend themselves against attacks by the predators. This defence consists of jerking of the abdomen and producing a droplet of rectal fluid. Thrips larvae can hit the predators with their abdomen, which may deter predators, and, while doing so, they can contaminate the predators with rectal fluid, which often leads to vigorous preening and retreating of the predator (Bakker and Sabelis 1986, 1989; Teerling et al. 1993a, 1993b; de Bruijn et al. 2006). The success of this defence increases with the size of the larva (Bakker and Sabelis 1986, 1989), and is more effective against predatory mites than against predatory bugs. Because thrips larvae have a higher developmental rate on host plants that are infected by the virus (Belliure et al. 2005), such infection could result in a shorter vulnerable period to predation of the larvae. Besides accelerating thrips development through infection of the host plant, the acquisition of TSWV by newly emerged larvae sometimes also directly results in their accelerated development, independent of the infection status of the host plant (Belliure et al. 2005). Hence, the presence of the virus in the vector and in the host plant of the vector would reduce the predation risk of the thrips larvae, and the virus would thus indirectly promote the survival of its vector.

Apart from this effect on the duration of the vulnerable period, the virus could also have an effect on the behaviour of vulnerable thrips larvae, which would also result in changes of predation risk. In general, behaviour of infected arthropods is known to change because of infection (Thomas et al. 2005), but such behavioural changes have not been studied in thrips larvae infected with TSWV. The virus circulates and replicates in thrips larvae (Ullman et al. 1992; Wijkamp and Peters 1993; Wijkamp et al. 1993; Nagata et al. 1999; Kritzman et al. 2002), and could therefore induce behavioural changes. For example, infected thrips larvae may differ from uninfected conspecifics in their defensive behaviour upon attack by predators, thereby affecting their vulnerability. Infection of thrips larvae could also affect their suitability as prey, and consequently, predators may preferentially feed on infected or uninfected larvae.

We studied the effects of the TSWV on the vulnerability of Western flower thrips larvae to predation. Specifically, we tested whether thrips larvae developing on TSWVinfected plant tissue had a decreased vulnerability to predators. We further tested whether this decreased vulnerability was the result of the increased growth rate of thrips larvae on TSWV-infected plant tissue or of different behaviour of thrips larvae from infected plant tissue upon attack by a predator. Moreover, we tested whether predators had differential preference for thrips larvae with and without the virus. To our best knowledge, this is the first investigation on the indirect effect of a plant virus on its herbivore vector through the third trophic level. 


\section{Materials and methods}

Plant material and virus isolate

All pepper plants (Capsicum annuиm L., var. Pikante Reuzen) used in the experiments were grown from seed in a climate room $\left[25^{\circ} \mathrm{C}, 50-70 \%\right.$ relative humidity $(\mathrm{RH})$, $16: 8 \mathrm{~h}$ light:dark (L:D)] in plastic pots $(11 \mathrm{~cm}$ high; diameter $10 \mathrm{~cm}$ ). Clean pepper plants were maintained free of virus and thrips and were not damaged in any way. The TSWV isolate used was Brazilian BR01 (De Avila et al. 1990). To obtain TSWV-infected plants, mechanical inoculations were performed as follows: $1 \mathrm{~g}$ of leaf material from pepper plants previously inoculated with the virus by thrips was triturated in $10 \mathrm{ml}$ of inoculation buffer (0.01 $\mathrm{M} \mathrm{NaPO}_{4}, \mathrm{pH}$ 7.0) (Maris et al. 2004). This inoculum was subsequently applied to clean plants by damaging the two first real leaves by dusting them with carborundum powder (500 mesh), and subsequently rubbing them with a sponge previously embedded in the inoculum. Such mechanically inoculated plants were used 2 weeks after inoculation. Infection of plants by the virus was checked by the development of symptoms typical for TSVW: chlorotic rings, chlorotic mosaic patterns, mottling on the leaves, growth reduction and deformation.

\section{Thrips}

Stock cultures of Frankliniella occidentalis (Pergande) were started from individuals collected in a commercial cucumber greenhouse near Pijnacker (The Netherlands) in May 1994, and were cultured on pepper plants in climate boxes $\left(25^{\circ} \mathrm{C}, 50-70 \% \mathrm{RH}, 16: 8 \mathrm{~h} \mathrm{~L}: \mathrm{D}\right)$ since 2002 . To obtain cohorts of thrips larvae of similar age, adult female thrips were allowed to oviposit on pepper leaves on which pine (Pinus sp.) pollen was provided to increase oviposition. The leaves were incubated in petri dishes (diameter $14 \mathrm{~cm}$ ) with wet cotton wool on the bottom to prevent desiccation. Females and pollen were removed after $48 \mathrm{~h}$, before the eggs hatched, to obtain a cohort of larvae that had been feeding on leaf tissue and not on pollen.

To obtain thrips larvae from TSWV-free plants (larvae that were not infected by the virus are referred to as "uninfected"), cohorts of thrips larvae were obtained from clean pepper plants, by allowing adults to oviposit on detached leaves. To obtain thrips larvae from TSWVinfected plants, cohorts were obtained on detached leaves from mechanically inoculated plants. Thrips larvae were allowed to feed on TSWV-infected leaf tissue for at least $48 \mathrm{~h}$ (acquisition access period). When feeding on infected plants as freshly emerged larvae, thrips become infected by the virus (Nagata and Peters 2001), hence we refer to these larvae as "infected".
Predators

Neoseiulus cucumeris (Oudemans) was reared on arenas consisting of a black PVC tile $\left(8 \times 15 \mathrm{~cm}^{2}\right)$ placed on a wet sponge in a plastic tray with water. Wet tissue was wrapped over the edges of each tile and a glue barrier was applied on the tissue. Mites were fed a mixture of pollen of Typha spp. and Vicia faba L. (broad bean) twice a week (Overmeer et al. 1989). Cultures consisted of several cohorts of similar-aged individuals, obtained by collecting recently laid eggs from an arena with adult females.

Iphiseius degenerans (Berl.) was reared on a diet of birch (Betula sp.) pollen on plastic arenas, as described by Van Rijn and Tanigoshi (1999). Arenas consisted of grey plastic sheets $\left(30 \times 21 \mathrm{~cm}^{2}\right)$ each subdivided into four rearing units with water-soaked paper tissues to provide water. Sheets were placed on wet sponges in a tray containing water. Mites were fed birch pollen twice per week (Faraji et al. 2000). Cultures consisted of several cohorts of similar-aged individuals.

Orius laevigatus (Fieber) were obtained from Koppert BV (The Netherlands) and reared according to the method described by van den Meiracker and Sabelis (1999) in plastic jars $\left(8 \times 8 \times 11 \mathrm{~cm}^{3}\right)$ with two lateral holes (diameter $4 \mathrm{~cm}$ ) covered with fine nylon gauze. Twice per week, Orius were fed eggs of the flour moth Ephestia kuehniella (Zeller) and provided with bean pods as oviposition substrate and moisture supply. Bean pods with predator eggs were collected regularly from jars with adults and placed in a new jar with flour-moth eggs to obtain cohorts of Orius with similar age. Jars were lined with crumpled tissue to provide hiding places for the juveniles and thus reduce cannibalism (van den Meiracker and Sabelis 1999).

\section{Effect of TSWV on body growth rates of thrips}

The growth in body size of thrips and the development into prepupae and into invulnerable size classes were recorded daily from egg hatching until adulthood. Newly emerged thrips larvae $(<24 \mathrm{~h}$ after emergence from egg) were placed on leaf discs (diameter $1.5 \mathrm{~cm}$ ) placed upside down in agar $(15 \%)$ in a petri dish (diameter $3.5 \mathrm{~cm}$ ). The agar helped to prevent desiccation of the leaf tissue and larvae from hiding underneath the leaf discs. The petri dish had a hole in the lid (diameter $2.5 \mathrm{~cm}$ ) covered with fine mesh gauze $(30 \mu \mathrm{m})$ to allow ventilation and avoid water condensation, yet prevent thrips escaping. Lids were sealed with parafilm to prevent larvae from escaping. The discs were incubated at $21^{\circ} \mathrm{C}$ and $16 \mathrm{~h}$ light. Leaf discs were obtained from clean plants (i.e. without damage or virus), or from plants that were mechanically inoculated with TSWV. Care was taken to prepare discs from leaves that 
showed no sign of mechanical damage. Larvae were transferred to fresh leaf discs of the same treatment every 3-4 days. Larvae that were tested on infected leaf tissue were collected from cohorts on infected leaves, hence these larvae were infected with the virus, and larvae that were tested on clean leaf discs came from cohorts on clean leaves and were uninfected. The length (from head to tip of the abdomen, excluding antennae) and width (the widest part of the abdomen) of thrips was measured daily under a stereoscope. The volume of the thrips larvae was estimated by calculating the volume of a cylinder with the length and width of the thrips. This overestimates the volume of thrips larvae because they are not tube-shaped, but the overestimation is consistent between thrips groups. The increase in body size of infected and uninfected larvae was estimated by fitting the curve

$S_{t}=\frac{S_{m} S_{0}}{S_{0}+\left(S_{m}-S_{0}\right) e^{-r t}}$

where $S_{t}=$ volume of the thrips at time $t ; S_{m}=$ maximum volume of thrips larvae; $S_{0}=$ minimum volume of thrips larvae, and $r=$ growth rate. $S_{0}$ was taken directly from the measurements of thrips larvae at the start of the experiment, and was identical for uninfected and infected larvae $\left(S_{0}=3.65 \times 10^{-3} \mathrm{~mm}^{3}\right) . S_{m}$ and $r$ were estimated by fitting this curve to the data. Differences in $r$ and $S_{m}$ of infected and uninfected thrips larvae were assessed with a $t$-test. The fitted curves were used in other experiments to estimate age of thrips larvae from their size. The development of infected and uninfected larvae into prepupae and into an invulnerable size was compared by using regression models of time-toevent data (Hosmer and Lemeshow 1999). The size of thrips larvae invulnerable to predation was assessed from the experiment on predation rate of predatory mites on thrips larvae of different sizes explained below.

Although the midgut of all thrips is infected when they acquire virus as newborn larvae, transmission is related to the infection and multiplication of the virus in the salivary glands (Nagata et al. 1999; Nagata and Peters 2001), and not all larvae that acquire the virus become TSWV transmitters (Sakimura 1962). Because it was possible that larvae that did not develop into transmitters would have growth rates comparable to uninfected larvae, we assessed the ability to transmit the virus of all thrips larvae that survived until adulthood in the growth experiment. The transmission ability of adults was checked with the petunia leaf disc assay: the adults were allowed to feed on petunia leaf discs for $48 \mathrm{~h}$ and the discs were checked for the presence of local lesions after $48 \mathrm{~h}$ (Wijkamp and Peters 1993). The growth rates of infected thrips that were either transmitters or non-transmitters were compared to detect a possible effect of transmission ability on growth rate of thrips.
Effect of the virus on predation rate

The predation rate of predatory mites on thrips larvae was measured on clean pepper leaf discs (diameter $5 \mathrm{~cm}$ ), placed upside down on wet cotton wool in a petri dish (diameter $14 \mathrm{~cm}$ ). Infected and uninfected thrips larvae were obtained from cohorts as described above (see section Thrips). To ensure that all larvae were of approximately the same size, larvae were measured under the stereoscope before placing them on the arenas. Five size classes commonly found during thrips development were used (size 15: $0.0043,0.0114,0.0133,0.0291$ and $0.0531 \mathrm{~mm}^{3}$ respectively). Five to ten replicates were carried out per size class. For each replicate, 20 thrips larvae, each of the same age and the same infection status, were placed on a leaf disc and were allowed to settle for $30 \mathrm{~min}$. Subsequently, a female predatory mite (either Neoseiulus or Iphiseius) was introduced on the leaf disc. The mites were 8-12 days old (from the egg stage) and were previously starved for $3 \mathrm{~h}$ to increase their motivation to attack prey. The leaf discs were maintained in a climate room $\left(25^{\circ} \mathrm{C}\right.$, $50-70 \% \mathrm{RH}$, and $16 \mathrm{~h}$ light). After $24 \mathrm{~h}$, dead and live larvae were counted under a stereoscope. The number of larvae that were found in the wet cotton wool or that were missing was also recorded. Controls were performed, in which mortality and escapes to the cotton wool were assessed in the absence of predators. The proportions of thrips larvae eaten were compared between treatments and among size classes for each predator species separately, using a generalized linear model (GLM) with binomial error distributions (R Development Core Team 2005). Contrasts among size classes were assessed through model simplification (Crawley 2002).

Predator preference and defensive behaviour of thrips larvae

Two types of choice test were performed with Neoseiulus and Iphiseius: (1) infected and uninfected larvae of the same size were offered simultaneously; (2) infected and uninfected larvae of the same age (and therefore different size, since infected larvae develop faster than uninfected larvae, see Fig. 1) were offered simultaneously. Infected and uninfected thrips larvae were obtained as described above (see section Thrips). The leaf discs (diameter $5 \mathrm{~cm}$ ) were from clean plants. Before the experiment, larvae were measured under the stereoscope to ensure similar size $\left(0.014 \mathrm{~mm}^{3}\right)$ or were taken from cohorts to ensure similar age (5 days old), respectively. In both cases, ten uninfected and ten infected thrips larvae were placed on the leaf disc and were allowed to settle for $30 \mathrm{~min}$. To enable the observer to discriminate between them, infected and uninfected larvae were painted with different colours of a 


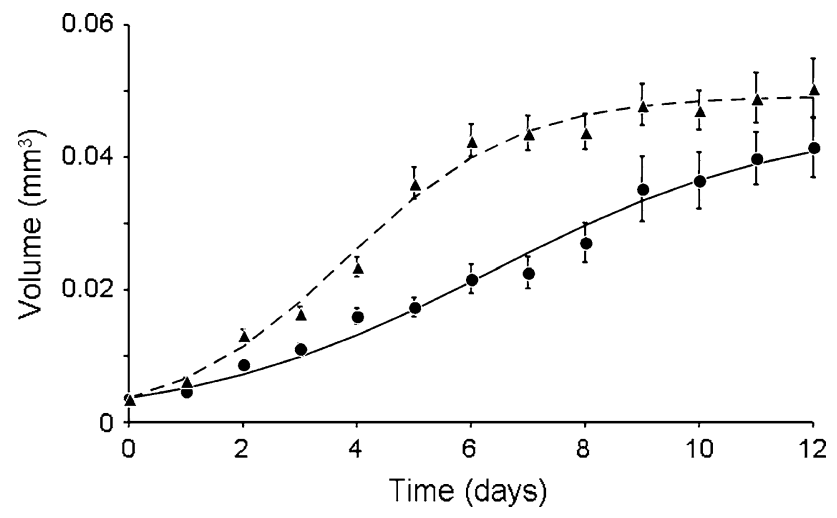

Fig. 1 Volume (in $\mathrm{mm}^{3}$ ) of thrips larvae versus age (in days), when developing on clean plants (circles uninfected larvae; $n=75$ ) and plants that were mechanically inoculated with Tomato spotted wilt virus (TSWV) (triangles infected larvae; $n=65$ ). Points show average values \pm SEM. Curves were obtained by fitting Eq. 1 to the data. For uninfected thrips larvae, the estimated growth rate $(r)$ is $0.384 \pm 0.019$, the maximum volume $\left(S_{m}\right)$ is $0.0455 \pm 0.0031$; for infected thrips $r=0.662 \pm 0.025$ and $S_{m}=0.0493 \pm 0.0012$. See text for further explanation

fluorescent powder, which was gingerly applied with a soft, moist, fine paintbrush. Although the powder does not affect predation rates (B. Belliure, personal observation), pink and blue powder was alternated between infected and uninfected larvae to avoid a possible effect of the powder on the preference of the predators. Adult female predatory mites, treated as above, were placed individually on the leaf disc. Larvae that were killed by the predators were replaced after 1 and $2 \mathrm{~h}$ of the experiment. Numbers of larvae killed were assessed after 1, 2 and $24 \mathrm{~h}$. Comparisons of predation rates on infected and uninfected thrips larvae were done with Wilcoxon signed ranks test.

Predatory bugs are much more voracious than predatory mites. The former may attack up to 18 thrips larvae per hour, but the latter attack and handle only a few thrips larvae per day. Predatory bugs are typically used for biological control of high thrips densities, whereas the predatory mites are used to keep thrips populations low. Because of the low per capita predation rate of predatory mites, we restricted behavioural observations of the interaction between thrips larvae and predators to those with the predatory bug Orius. We performed a choice test with infected and uninfected larvae of the same age (4 days old), and therefore with infected larvae which were larger than uninfected larvae. Young adult female Orius (ca. 2 days after moulting to adulthood) were used after having been starved for $24 \mathrm{~h}$. Similar leaf discs were used as above, but the experiment lasted for $1 \mathrm{~h}$. During the experiment, all larvae eaten by Orius were replaced with new larvae that had been exposed to the same treatment to maintain equal numbers of infected and uninfected larvae. Comparisons of predation rates on the two prey types were performed with a Wilcoxon signed ranks test in all cases. During these experiments, the behaviour of predator and prey attacked were observed continuously and recorded using the software Etholog 2.2 (Ottoni 2000). The time that Orius spent searching (i.e. walking), resting (i.e. being immobile), cleaning (i.e. preening body, antennae or other legs with legs) was registered, as well as the number and time of encounters, attacks, handling time and feeding time of infected and uninfected thrips larvae. From these data, we calculated the encounter rates with infected and uninfected thrips larvae (i.e. number of encounters divided by search time), the attack success ratio (number of attacks ending with feeding of the predator and death of the prey divided by the number of encounters), and the predation rate (number of thrips larvae eaten per hour). We also recorded whether thrips larvae escaped (i.e. ran away from predators), and whether they defended themselves (i.e. jerking the abdomen, Bakker and Sabelis 1989) after an encounter with the predator. Behaviour of Orius towards infected and uninfected thrips larvae as well as behaviour of infected and uninfected thrips larvae were compared using a Wilcoxon signed ranks test.

\section{Results}

Effect of virus on development and body growth of thrips

Infected larvae developed faster into prepupae than uninfected larvae (log-rank test: $\chi^{2}=26.3, d f=1, P<0.0001$ ). The body size of uninfected larvae increased significantly slower than that of infected larvae (Fig. $1 ; t$-test: $d f=138$, $P=0.0001)$. Larvae reached the prepupa stage and stopped growing when 8-12 days old, and infected and uninfected prepupa were not significantly different in size (Fig. 1; $t$-test: $d f=47, P=0.21$ ), indicating that infected larvae did not grow into larger prepupae, but grew faster. Similar results were obtained with thrips larvae that were raised on tissue from plants that were infected with the virus by thrips rather than inoculated mechanically (B. Belliure, personal observation).

Some $22.7 \%$ of the adult thrips obtained from the infected larvae were able to transmit the virus $(n=22)$. This percentage is within the range of transmission efficiency reported elsewhere (van de Wetering et al. 1999). None of the adults from the control (uninfected larvae) was able to transmit TSWV $(n=6)$. Within the infected larvae, there was no difference in growth rate between larvae that developed into transmitters and non-transmitters (log-rank test, $\chi^{2}=0.139 ; d f=1, P=0.89$ ), indicating that all larvae developing on infected plant tissue grew faster than larvae on uninfected plant tissue, regardless of their ability to transmit the virus as adults. 
Effect of the virus on predation rate

The size of thrips larvae had a significant effect on predation rate by both predatory mites (Fig. 2; GLM, Neoseiulus, $F=23.2, d f=4,76, P<0.0001$; Iphiseius, $F=70.4, d f=4,86, P<0.0001)$. Uninfected and infected thrips larvae of the same size suffered similar predation rates from Neoseiulus (Fig. 2; GLM, $F=0.0086, d f=1$, 76, $P=0.926)$. Predation rates of Neoseiulus differed among size classes, except between size classes 2 and 3, and between size classes 4 and 5 (Fig. 2). For Iphiseius, there was a significant interaction between size and state of infection (Fig. 2; GLM, $F=5.96, d f=4,82$, $P<0.0001)$. Contrasts showed that there was a significant effect of infection on predation within size class 2 (Fig. 2; $z$-value $=3.73, P=0.0002$ ), where infected thrips larvae were attacked more than uninfected larvae. There was no effect of infection of thrips on predation rate in the other size classes.

Only few thrips larvae escaped to the cotton wool or were missing (altogether 2.84 per replicate on average), and the number of larvae that escaped did not differ among treatments, indicating that predators did not induce the prey to escape from the leaf discs.

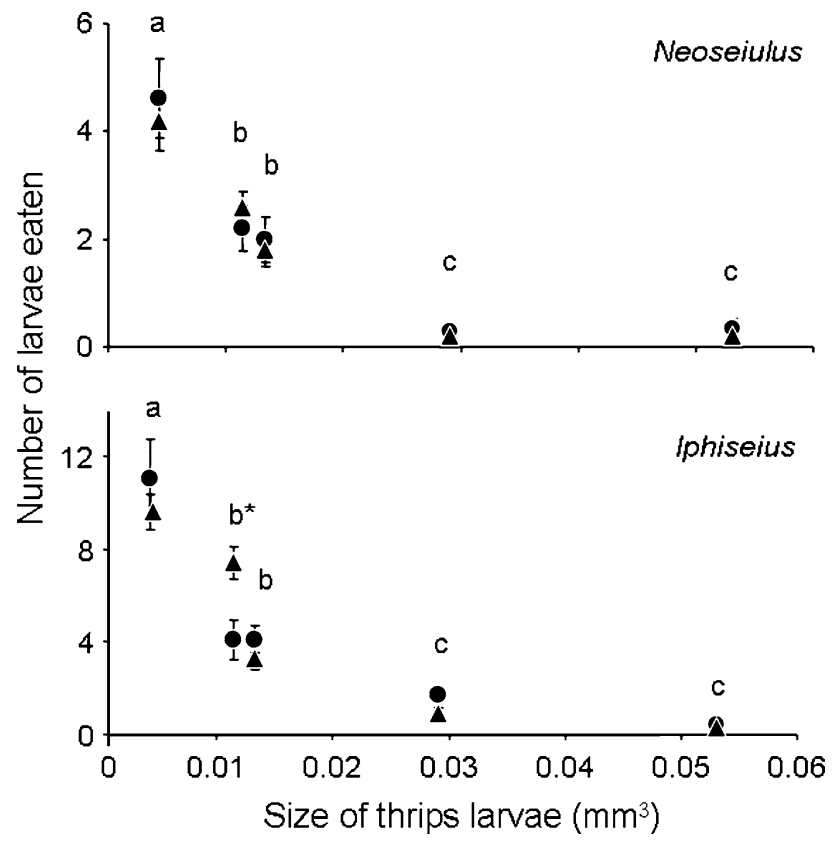

Fig. 2 Predation rates $\left(\right.$ day $^{-1}$ ) (average \pm SEM) of the predatory mites Neoseiulus and Iphiseius on thrips larvae infected with TSWV (triangles) and on uninfected thrips larvae (circles) of five different sizes $\left(0.0043,0.0114,0.0133,0.0291\right.$ and $0.0531 \mathrm{~mm}^{3}$ approximately). Predation on size classes accompanied by the same letter was not significantly different (comparison for each predator separately). $* P<0.05$ for predation on infected and uninfected thrips larvae
Thrips larvae of size class $4\left(0.029 \mathrm{~mm}^{3}\right)$ were largely invulnerable to predation by both predatory mite species (Fig. 2). This invulnerable size was reached by uninfected larvae after 7.9 days, whereas infected larvae were already invulnerable after 4.4 days (Fig. 1). Hence, developing on infected plant tissue resulted in a significant reduction of the vulnerable period by 3.5 days (Regression of time to reaching an invulnerable size: Log-rank test, $\chi^{2}=3.09$, $d f=1, P=0.0020)$. Although adult males were smaller than adult females in both treatments (Mann-Whitney $U$, uninfected: $P=0.0079$; infected: $P<0.0001)$, there were no differences within treatments in growth rates of males and females until reaching this invulnerable size (log-rank test, n.s.). Larvae on tissue from plants inoculated with TSWV by thrips also reached the invulnerable size sooner than larvae on tissue from plants with thrips damage, yet free of virus (B. Belliure personal observation).

When plotting the observed predation rates as a function of the estimated age of the larvae rather than their size, it becomes clear that infected and uninfected larvae of similar age are likely to experience different predation rates (Fig. 3).

Predator preference and defensive behaviour of thrips larvae

We performed a choice experiment with infected and uninfected larvae of the same age (thus differing in size) to

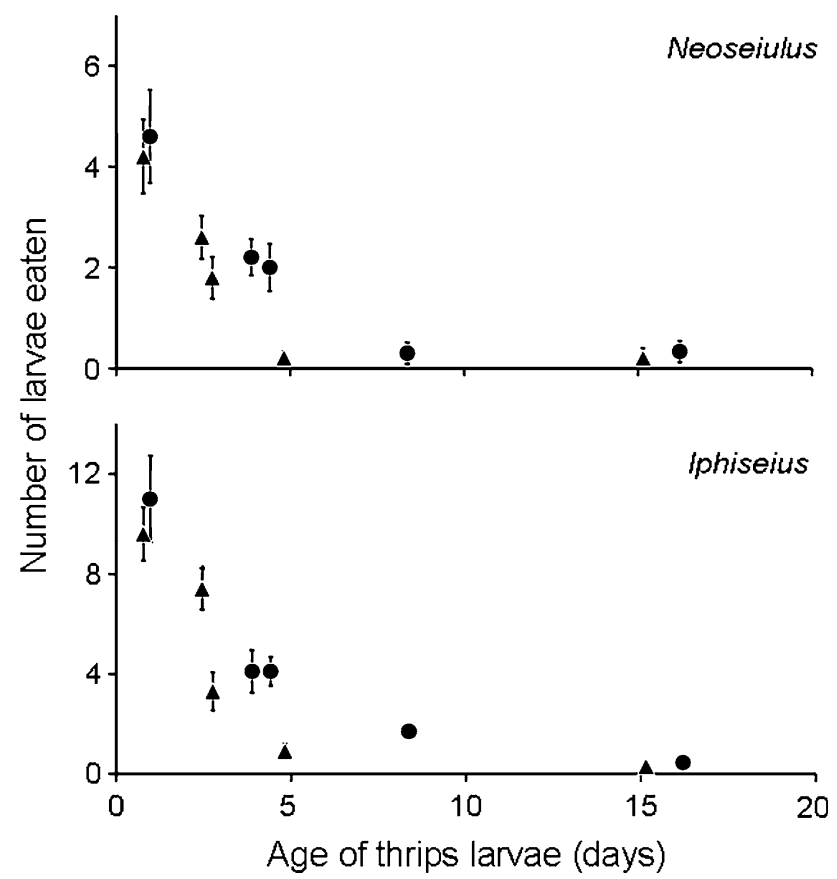

Fig. 3 Predation rate $\left(\right.$ day $\left.^{-1}\right)$ (average \pm SEM) of the predatory mites Neoseiulus and Iphiseius on thrips larvae infected with TSWV (triangles) and uninfected thrips larvae (circles) as function of the estimated age (in days) of thrips larvae 


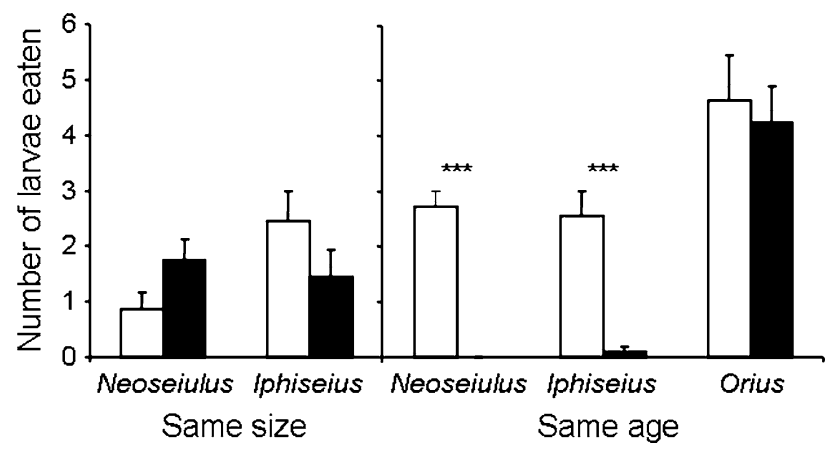

Fig. 4 Average number (+SEM) of infected (black) and uninfected (white) thrips larvae eaten in two-choice tests. Left panel Infected and uninfected larvae of the same size eaten by Neoseiulus (number of tests $=8$ ) and Iphiseius (number of tests $=9$ ) during $24 \mathrm{~h}$. Right panel Infected and uninfected larvae of the same age eaten by Neoseiulus (number of tests $=10$ ) and Iphiseius (number of tests $=11$ ) during $24 \mathrm{~h}$, and by Orius (number of tests $=13$ ) during $1 \mathrm{~h} . * * * P<0.05$ for predation between uninfected and infected thrips larvae

test whether they indeed experience different predation risks. Moreover we did a choice experiment with infected and uninfected larvae of the same size, hence, differing in age. When thrips larvae were of the same age (hence, infected larvae were larger), both predatory mites killed more uninfected than infected thrips larvae (Fig. 4; right panel, Wilcoxon signed ranks test, Neoseiulus, $P<0.005$; Iphiseius, $P<0.005$ ). Neither of the two predatory mite species showed a preference for infected or uninfected thrips larvae when the larvae were of the same size (Fig. 4; left panel, Wilcoxon signed ranks test, Neoseiulus, $P=0.149$, Iphiseius, $P=0.21$ ). The predatory bug Orius, however, did not show any preference for infected or uninfected larvae of the same age (Fig. 4; right, Wilcoxon signed ranks test, $P=0.86$ ). There were no significant differences in the encounter rate, attack success rate, predation rate, handling time, or feeding time of Orius with respect to infected versus uninfected larvae (Wilcoxon signed ranks tests, all differences not significant). Upon encounter with the predatory bug, infected and uninfected thrips larvae showed no difference in behaviour (Wilcoxon signed ranks tests, differences non-significant).

\section{Discussion}

In some plant-herbivore-pathogen systems, direct defences induced by herbivores are countered by plant viruses through the negative cross-talk between the metabolic pathways activated by both challengers (Felton et al. 1999; Felton and Korth 2000; Thaler et al. 2002a, b; Pieterse and Van Loon 2004), whereas in other systems herbivores and pathogens induce reciprocal resistance in plants (Stout et al. 1999, 2006). Mechanisms to suppress the defences induced in plants by arthropod herbivores may have evolved in vector-borne plant viruses because they promote the spread of the virus (Belliure et al. 2005). Our experiments show that the indirect anti-herbivore defence, mediated through the third trophic level, is also alleviated by a plant virus. The vulnerability of thrips larvae to predation by the phytoseiid mites Neoseiulus and Iphiseius was reduced for those larvae developing on tissue from plants infected with TSWV. The growth rate of thrips larvae on infected plant tissue was higher than on uninfected plant tissue, resulting in infected thrips larvae reaching an invulnerable size at a much younger age than uninfected larvae. As a result, the predation rate on thrips larvae from infected plant tissue was lower than on thrips larvae of the same age from uninfected plant tissue.

We did not find a difference in rate of predation with uninfected and infected larvae of the same size, hence, different in age. This suggests that preference of the predator is not affected by virus infection of the prey. This was further confirmed by the finding that the predatory bug, which is capable of feeding on all sizes of thrips larvae, did not show a preference and did not perform differential attack behaviour towards infected or uninfected larvae of different size but the same age.

In theory, the virus could also directly change the behaviour of the thrips larvae (Thomas et al. 2005), especially the larval defence behaviour (Bakker and Sabelis 1986, 1989). Behavioural observations of thrips larvae in the presence of Orius showed that infected and uninfected thrips larvae defended themselves in virtually the same way. In conclusion, TSWV reduces the predation risk of larvae of its vector through increased growth rate only, and not through changes in prey or predator behaviour.

All three species of predators are effective in controlling thrips populations. Predatory mites have low per capita predation rates, but are capable of suppressing thrips populations because of their high population growth rates (van Rijn et al. 2002). They are commonly used to prevent outbreaks of thrips. In contrast, predatory bugs like Orius have a high per capita growth rate but a low population growth rate (van de Meiracker and Sabelis 1999), and are used to reduce thrips populations when their densities are high. Both types of predators are important mortality factors for thrips. The reduction of the predation risk by predatory mites may therefore have a positive effect on thrips densities and will result in increased spread of the virus.

Possibly, there are additional indirect effects of the virus on thrips mediated through the third trophic level. For example, many plants are known to produce volatiles upon attack by herbivores, and these volatiles attract natural enemies of the herbivores (Sabelis and Van der Baan 1983; Dicke and Sabelis 1988; Turlings et al. 1990; Dicke et al. 1990, 1998; Takabayashi and Dicke 1996; Janssen 1999; 
Sabelis et al. 1999). These volatiles are produced through the jasmonic acid-mediated metabolic pathway (Hopke et al. 1994; Thaler et al. 2002a; Gols et al. 2003; Ament et al. 2004). Thrips are also known to induce volatile emission (Delphia et al. 2007). The infection of plants with virus may interfere with the production of such volatiles through inhibition of the jasmonic acid signalling pathway and may thus further affect the predation risk of thrips larvae.

From the point of view of the virus, it is adaptive to promote thrips fitness because this increases virus dispersal. Our studies show that thrips benefit from developing on infected plants, both from the effect of TSWV on direct defence of plants and from the effect on indirect defence through their natural enemies. Therefore, it comes as no surprise that thrips prefer infected plants to lay their eggs (Carter 1939, Bautista et al. 1995, Maris et al. 2004). This preference for infected plants is adaptive for thrips when the virus is not so virulent as to kill infected plants before the offspring of the thrips reach adulthood. Because direct and indirect defences are common in many plant-virus-vector systems (Walling 2000), we expect such beneficial effects of a virus on its vectors to occur more generally.

The lower vulnerability to predation by phytoseiid mites of infected thrips larvae is likely to have consequences for the epidemiology of the virus. To our knowledge, the results in this article represent the first example of a positive effect of a plant virus on its vector through the third trophic level. The interactions between virus, vector and plants should thus be studied within the context of the food web of organisms living on these plants.

Acknowledgements We thank Paul Maris and Dick Peters (Wageningen University and Research Centre) for support and for providing the TSWV isolate, and Marta Artal (SILS, University of Amsterdam) for providing help and material for the inoculation buffer. Matilde Galli, Sarah Doornbos and Jesse Blits performed promising pilot experiments. Cristina Bas, Paulien de Bruijn, Martijn Egas, João Ferreira, Amir Grosman, Tessa van der Hammen, Roos van Maanen, Sara Magalhães, Marta Montserrat, Maria Nomikou and Christian Tudorache are thanked for stimulating discussions. The comments of two anonymous reviewers greatly improved the manuscript. Belén Belliure was the recipient of an Individual Marie Curie Fellowship (contract HPMF-CT-2002-01665). The experiments performed comply with the current laws of The Netherlands.

Open Access This article is distributed under the terms of the Creative Commons Attribution Noncommercial License which permits any noncommercial use, distribution, and reproduction in any medium, provided the original author(s) and source are credited.

\section{References}

Agrawal AA (1998) Induced responses to herbivory and increased plant performance. Science 279:1201-1202
Agrawal AA, Klein CN (2000) What omnivores eat: direct effects of induced plant resistance on herbivores and indirect consequences for diet selection by omnivores. J Anim Ecol 69:525-535

Ament K, Kant MR, Sabelis MW, Haring MA, Schuurink RC (2004) Jasmonic acid is a key regulator of spider mite-induced volatile terpenoid and methyl salicylate emission in tomato. Plant Physiol 135:2025-2037

Bakker FM, Sabelis MW (1986) Attack success of Amblyseius mckenziei and the stage related defensive capacity of thrips larvae. Mededelingen der Faculteit Landbouwwetenschappen, Rijksuniversiteit Gent 51/3A:1041-1044

Bakker FM, Sabelis MW (1989) How larvae of Thrips tabaci reduce the attack success of phytoseiid predators. Entomol Exp Appl 50:47-51

Bautista RC, Mau RFL, Cho JJ, Custer DM. (1995) Potential of Tomato spotted wilt tospovirus plant nests in Hawaii as virus reservoirs for transmission by Frankliniella occidentalis (Thysanoptera, Thripidae). Phytopathology 85:953-958

Belliure B, Janssen A, Maris PC, Peters D, Sabelis MW (2005) Herbivore arthropods benefit from vectoring plant viruses. Ecol Lett 8:70-79

Bostock RM (1999) Signal conflicts and synergies in induced resistance to multiple attackers. Physiol Mol Plant Pathol 55: 99-109

Carter W (1939) Populations of Thrips tabaci, with special reference to virus transmission. J Anim Ecol 8:261-276

Crawley MJ (2002) Statistical computing. An introduction to data analysis using S-Plus. Wiley and Sons, Chichester

De Avila AC, Huguenot C, Resende RD, Kitajima EW, Goldbach RW, Peters D (1990) Serological differentiation of 20 isolates of Tomato spotted wilt virus. J Gen Virol 71:2801-2807

de Bruijn PJA, Egas M, Janssen A, Sabelis MW (2006) Pheromoneinduced priming of a defensive response in Western flower thrips. J Chem Ecol 32:1599-1603

Delphia CM, Mescher MC, De Moraes CM (2007). Induction of plant volatiles by herbivores with different feeding habits and the effects of induced defences on host-plant selection by thrips. J Chem Ecol 33:997-1012

Dicke M, Sabelis MW (1988) How plants obtain predatory mites as bodyguards. Neth J Zool 38:148-165

Dicke M, Takabayashi J, Posthumus MA, Scütte C, Krips OE (1998) Plant-phytoseiid interactions mediated by herbivore-induced plant volatiles: variation in production of cues and in responses of predatory mites. Exp Appl Acarol 22:311-333

Dicke M, Sabelis MW, Takabayashi J, Bruin J, Posthumus MA (1990) Plant strategies of manipulating predator-prey interactions through allelochemicals-prospects for application in pestcontrol. J Chem Ecol 16:3091-3118

Drukker B, Scutareanu P, Sabelis MW (1995) Do anthocorid predators respond to synomones from psylla-infested pear trees under field conditions? Entomol Exp Appl 77:193-203

Faraji F, Janssen A, Van Rijn PCJ, Sabelis MW (2000) Kin recognition by the predatory mite Iphiseius degenerans: discrimination among own, conspecific, and heterospecific eggs. Ecol Entomol 25:147-155

Felton GW, Korth KL (2000) Trade-offs between pathogen and herbivore resistance. Curr Opin Plant Biol 3:309-314

Felton GW, Korth KL, Bi JL, Wesley SV, Huhman DV, Mathews MC, Murphy JB, Lamb C, Dixon RA (1999) Inverse relationship between systemic resistance of plants to microorganisms and to insect herbivory. Curr Biol 9:317-320

Gols R, Roosjen M, Dijkman H, Dicke M (2003) Induction of direct and indirect plant responses by jasmonic acid, low spider mite densities, or a combination of jasmonic acid treatment and spider mite infestation. J Chem Ecol 29:2651-2666 
Hopke J, Donath J, Blechert S, Boland W (1994) Herbivore-induced volatiles - the emission of acyclic homoterpenes from leaves of Phaseolus lunatus and Zea mays can be triggered by a betaglucosidase and jasmonic acid. FEBS Lett 352:146-150

Hosmer DWJ, Lemeshow S (1999) Applied survival analysis. Regression modeling of time to event data. Wiley-Interscience, New York

Janssen A (1999) Plants with spider-mite prey attract more predatory mites than clean plants under greenhouse conditions. Entomol Exp Appl 90:191-198

Janssen A, Pallini A, Venzon M, Sabelis MW (1998) Behaviour and indirect interactions in food webs of plant-inhabiting arthropods. Exp Appl Acarol 22:497-521

Karban R, Baldwin IT (1987) Induced plant responses to herbivory. University of Chicago Press, Chicago

Kessler A, Baldwin IT (2001) Defensive function of herbivoreinduced volatiles in nature. Science 291:2141-2144

Kritzman A, Gera A, Raccah B, van Lent JWM, Peters D (2002) The route of Tomato spotted wilt virus inside the thrips body in relation to transmission efficiency. Arch Virol 147:2143-2156

Lefcort H, Durden LA (1996) The effect of infection with Lyme disease spirochetes (Borrelia burgdorferi) on the phototaxis, activity, and questing height of the tick vector Ixodes scapularis. Parasitology 113:97-103

Maris PC, Joosten NN, Goldbach RW, Peters D (2004) Tomato spotted wilt virus infection improves host suitability for its vector Frankliniella occidentalis. Phytopathology 94:706-711

Nagata T, Peters D (2001) An anatomical perspective of Tospovirus transmission. In: Harris KF, Smith OP, Duffus JE (eds) Virusinsect-plant interactions, Academic Press, New York, pp 51-67

Nagata T, Inoue-Nagata AK, Smid HM, Goldbach R, Peters D (1999) Tissue tropism related to vector competence of Frankliniella occidentalis for tomato spotted wilt tospovirus. J Gen Virol 80:507-515

Ottoni EB (2000) EthoLog 2.2: a tool for the transcription and timing of behavior observation sessions. Behav Res Meth Instrum Comput 32:446-449

Overmeer WPJ, Nelis HJCF, Deleenheer AP, Calis JNM, Veerman A (1989) Effect of diet on the photoperiodic induction of diapause in 3 species of predatory mite, Amblyseius potentillae, Amblyseius cucumeris and Typhlodromus pyri. Exp Appl Acarol 7:281287

Pieterse CM, Van Loon L (2004) NPR1: the spider in the web of induced resistance signaling pathways. Curr Opin Plant Biol 7:456-464

Pieterse CMJ, van Loon LC (1999) Salicylic acid-independent plant defence pathways. Trends Plant Sci 4:52-58

Price PW, Bouton CE, Gross P, McPheron BA, Thompson JN, Weiss AE (1980) Interactions among three trophic levels: Influence of plants on interactions between insect herbivores and natural enemies. Annu Rev Ecol Syst 11:41-65

R Development Core Team (2005) R: A language and environment for statistical computing. R Foundation for Statistical Computing, Vienna, Austria. ISBN 3-900051-07-0. http://www.R-project.org

Rostas M, Ton J, Mauch-Mani B, Turlings TCJ (2006) Fungal infection reduces herbivore-induced plant volatiles of maize but does not affect naive parasitoids. J Chem Ecol 32(9):1897-1909

Sabelis MW, Janssen A, Pallini A, Venzon M, Bruin J, Drukker B, Scutareanu P (1999) Behavioural responses of predatory and herbivorous arthropods to induced plant volatiles: from evolutionary ecology to agricultural applications. In: Agrawal AA, Tuzun S, Bent E (eds) Induced plant defenses against pathogens and herbivores. American Phytopathological Society Press, St. Paul, pp 269-296

Sabelis MW, Van der Baan HE (1983) Location of distant spider-mite colonies by phytoseiid predators-demonstration of specific kairomones emitted by Tetranychus urticae and Panonychus ulmi. Entomol Exp Appl 33:303-314

Sakimura K (1962) The present status of thrips-borne viruses. In: Maramorosch K (ed) Biological transmission of disease agents. Academic, New York

Spoel SH, Koornneef A, Claessens SMC, Korzelius JP, Van Pelt JA, Mueller MJ, Buchala AJ, Metraux JP, Brown R, Kazan K, van Loon LC, Dong XN, Pieterse CMJ (2003) NPR1 modulates cross-talk between salicylate- and jasmonate-dependent defense pathways through a novel function in the cytosol. Plant Cell 15:760-770

Stout MJ, Fidantsef AL, Duffey SS, Bostock RM (1999) Signal interactions in pathogen and insect attack: systemic plantmediated interactions between pathogens and herbivores of the tomato, Lycopersicon esculentum. Physiol Mol Plant Pathol 54(3-4):115-130

Stout MJ, Thaler JS, Thomma BPHJ (2006) Plant-mediated interactions between pathogenic microorganisms and herbivorous arthropods. Annu Rev Entomol 51:663-689

Stumpf CF, Kennedy GG (2007) Effects of tomato spotted wilt virus isolates, host plants, and temperature on survival, size, and developent time of Frankliniella occidentalis. Entomol Exp Appl 123:139-147

Takabayashi J, Dicke M (1996) Plant-carnivore mutualism through herbivore-induced carnivore attractants. Trends Plant Sci 1:109_ 113

Teerling CR, Gillespie DR, Borden JH (1993a) Utilization of Western flower thrips alarm pheromone as a prey-finding kairomone by predators. Can Entomol 125:431-437

Teerling CR, Pierce HD, Borden JH, Gillespie DR (1993b) Identification and bioactivity of alarm pheromone in the Western flower thrips, Frankliniella occidentalis. J Chem Ecol 19:681-697

Thaler JS (1999) Jasmonate-inducible plant defences cause increased parasitism of herbivores. Nature 399:686-688

Thaler JS, Fidantsef AL, Duffey SS, Bostock RM (1999) Trade-offs in plant defense against pathogens and herbivores: a field demonstration of chemical elicitors of induced resistance. J Chem Ecol 25:1597-1609

Thaler JS, Farag MA, Pare PW, Dicke M (2002a) Jasmonate-deficient plants have reduced direct and indirect defences against herbivores. Ecol Lett 5:764-774

Thaler JS, Karban R, Ullman DE, Boege K, Bostock RM (2002b) Cross-talk between jasmonate and salicylate plant defense pathways: effects on several plant parasites. Oecologia 131:227-235

Thomas F, Adamo S, Moore J (2005). Parasitic manipulation: where are we and where should we go? Behav Process 68:185-199

Turlings TCJ, Tumlinson JH, Lewis WJ (1990) Exploitation of herbivore-induced plant odors by host-seeking parasitic wasps. Science 250:1251-1253

Ullman DE, Cho JJ, Mau RFL, Hunter WB, Westcot DM, Custer DM (1992) Thrips-Tomato spotted wilt virus interaction: morphological, behavioral and cellular components influencing thrips transmission. In: Harris KF (ed) Advances in disease vector research. Springer, New York, pp 195-240

van den Meiracker RAF, Sabelis MW (1999) Do functional responses of predatory arthropods reach a plateau? A case study of Orius insidiosus with Western flower thrips as prey. Entomol Exp Appl 90:323-329

van Rijn PCJ, Tanigoshi LK (1999) The contribution of extrafloral nectar to survival and reproduction of the predatory mite Iphiseius degenerans on Ricinus communis. Exp Appl Acarol 23:281-296

van Rijn PCJ, van Houten YM, Sabelis MW (2002). How plants benefit from providing food to predators even when it is also edible to herbivores. Ecology 83:2664-2679 
van de Wetering F, van der Hoek M, Goldbach R, Mollema C, Peters D (1999) Variation in tospovirus transmission between populations of Frankliniella occidentalis (Thysanoptera: Thripidae). Bull Entomol Res 89:579-588

Walling LL (2000) The myriad plant responses to herbivores. J Plant Growth Regul 19:195-216
Wijkamp I, Peters D (1993) Determination of the median latent period of 2 Tospoviruses in Frankliniella occidentalis, using a novel leaf disk assay. Phytopathology 83:986-991

Wijkamp I, Vanlent J, Kormelink R, Goldbach R, Peters D (1993) Multiplication of Tomato spotted wilt virus in its insect vector, Frankliniella occidentalis. J Gen Virol 74:341-349 